1983 at Aachen, a Programme Committee has been set up, chaired by E. Hintz (Jülich). Members are A. Gibson (Abingdon), J. Jacquinot (Fontenay-aux-Roses), D.D. Ryutov (Novosibirsk), F. Troyon (Lausanne), and R. Wienecke (Stuttgart). As the format of the Moscow Conference was considered to be very satisfactory, it was agreed to follow the same lines at Aachen. The Organizing Committee of the Conference will be chaired by G. H. Wolf (Jülich).

The EPS Council has approved the application of a new formula for the submission of contributed papers to the Conference. Colleagues who are not individual members of EPS nor members of EPS Member Societies nor on the staff of organizations which are Associate Members of EPS, will need sponsorship for submitting a contribution. This can be given either by an individual member of EPS (with an upper limit of two papers per individual member) or by a Member Society. The introduction of this rule derives from the conviction of the Board that EPS membership must be made more attractive. The Divisional Conference at Aachen is taking place in the week following the International Conference on lonization Phenomena in Gases at Düsseldorf, so that participation in both events will be very much eased in 1983

A question which received much attention at both this meeting of the Board and in the General Assembly of EPS is that of free access of members to the Conferences organized by the Division. There was complete agreement on all sides that this was an established right, but it was recognized that there are a number of practical points connected with this right which have to be made more precise.

Although the number of members of the Division has somewhat increased during the past year (it totals now about 270), the situation is still far from being satisfactory. Continuing efforts of all members are therefore necessary to convince more colleagues to join EPS and the Division. Only with an increasing number of individual members will EPS and the Division be able

\title{
Official Announcements
}

In Istanbul, Council gave tacit agreement to the principle that the unit fee should follow the inflation experienced in Switzerland. As Council will meet only once in 1982 it will be invited at its meeting on 1-2 April 1982 to approve the following:

In accordance with the provisions of Rules 34 and 35 of the By-Laws, the Council agrees that the Unit fee shall be raised from Sw.Fr. 9. - to Sw.Fr. 10.from 1 January 1983.

\section{Divisional Boards}

The following members have been coopted on to Divisional Boards:

Condensed Matter Division

$$
\begin{aligned}
& \text { H. Grimmeiss, Lund } \\
& \text { V. Heine, Cambridge } \\
& \text { E. Mooser, Lausanne } \\
& \text { F. Mueller, Nijmegen }
\end{aligned}
$$

\section{Nuclear Physics Division}

G. Tibell, Gustaf Werners Inst., Uppsala

I. Ulehla, University, Prague

H. Zingl, University, Graz

New Chairman of the Nuclear Physics Division is: P. von Brentano, Cologne following the resignation of $\mathrm{V}$. Meyer.

to extend its activities and give better service to the physics community in Europe.

A number of loose contacts between the Division and the Plasma Physics Sections of the EPS Member Societies have been established, but in this field also further efforts are necessary.

Unfortunately, it was not possible in Moscow to constitute the new Board of the Plasma Physics Division whose term starts on 1 January 1982, because only a very small number of its members were able to participate in the meeting that had been arranged. Elections to the Board have recently taken place (see Europhysics News, 12, (1981) 8/9 p. 12) and the constitution of the Board is now being established by written procedure. The outcome will be communicated as soon as possible.

\section{F. Engelmann}

At the meeting of Council held in Istanbul on 6 Sept. 1981, it was agreed that the Executive Committee should present proposals to provide for the admission to the EPS, of physicists who are members of other major regional physical societies with which Council has agreed to collaborate.

In accordance with this instruction, Council will be invited to approve at its next meeting on 1-2 April 1982, the definition of a new category of individual membership, by agreeing to the following changes to the Constitution and By-laws.

\section{Constitution}

ARTICLE 4

Add:

d) individuals who are members of a society or group which is not an Ordinary Member, Category 4b) but has been approved by Council as a Collaborating Society.

ARTICLE 16

Subsection bl, replace line 2 by:

individual members of Categories a), c) and d) mentioned in Article 4, as

\section{By-Laws}

RULE 1

Add:

or a Collaborating Society.

RULE 19

Replace in line 2, Article 4a) and c) by: Article 4a), c) and d)

RULE 35

Add:

d) Individual Ordinary Members, Constitution Article $4 \mathrm{~d}$, who are thus also members of a Collaborating Society.

Such number of units as decided by Council for each Collaborating Society

Note: the two paragraphs in RULE 35 are positioned opposite each other.

RULE 36

Replace by:

Fellows shall pay as Individual Ordinary Members, Rule 35a), c) or d).

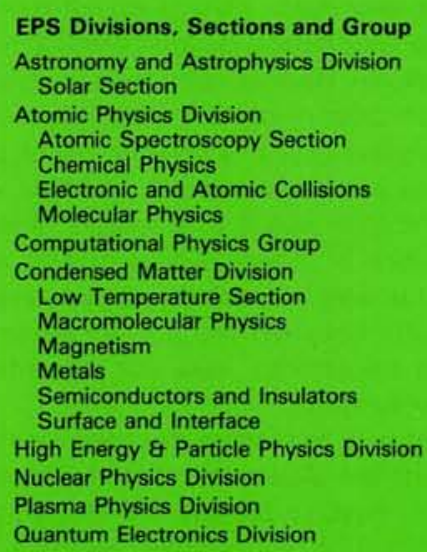

Europhysics News is the official journal of the European Physical Society that comprises 28 National Societies, Academies and Groups, over 3000 Individual Ordinary Academies and Groups, over 300 individual Ordinary of EPS are the General Meeting, Council and an elected Executive Committee responsible for detailed policy. EPS promotes the collaboration of physicists throughout Europe and encourages all aspects of international exchange in physics. EPS awards scholarships for research and studies and makes arrangements for tea. ching abroad. EPS publishes, in addition to Europhysics News, Europhysics Conference Abstracts, the Procee dings of its General Conferences and (with the I.O.P.) the European Journal of Physics. Individual Ordinary Members receive Europhysics News (subscription for non-members: $82 \mathrm{Sw}$. Fr./al, substantial rebates on publications and pay reduced fees at conferences Application for membership is made through the perApplication for membership is made through the permembers of a National Society will be Sw.Fr. 36 in 1982

\section{Editor: E.N. Shaw}

Meetings Compilation: W.S. Newman

Editorial Board:

K. Appert, A. Baratoff, G.J. Béné,

G.R. Macleod, A. Maeder, J. Muller

Editorial and Advertising Office at the EPS Secretariat.

Address: EUROPEAN PHYSICAL SOCIETY P.O. Box 69 , CH-1213 Petit-Lancy 2 Switzerland

Telephone: Geneva (22) 931130

Telex: 23455 alarm ch

Cables: europhys genève

Printed by: Pfirter frères SA

CH-1213 Petit-Lancy/Switzerland 